\title{
Development of Student Worksheeet Based on Blended Learning Oriented to Multiple Intelligences in Algebra
}

\author{
$1^{\text {st }}$ Irmawaty Natsir* \\ Department of Mathematics Education \\ Universitas Musamus \\ Merauke, Indonesia \\ natsir_fkip@unmus.ac.id
}

\author{
$2^{\text {st }}$ Anis Munfarikhatin \\ Department of Mathematics Education \\ Universitas Musamus \\ Merauke, Indonesia \\ munfarikhatin_fkip@unmus.ac.id
}

\author{
$3^{\text {st }}$ Abdul Rachman Taufik \\ Department of Mathematics Education \\ Universitas Musamus \\ Merauke, Indonesia \\ taufik_fkip@unmus.ac.id
}

\begin{abstract}
The era of the industrial revolution 4.0, the development of science and technology needs to be balanced with the ability of students to solve problems based on their intelligence, not only from the IQ level. This research is a Reseach and Development ( $\&$ \& $)$ study using the ADDIE model which consists of five stages. However, in this study the authors limit only to the third stage. The purpose of this study is to produce a student worksheet based on blended learning that is oriented towards multiple intelligences in algebra courses. The student worksheets arranged in this study are adjusted to the dominant intelligence of the students. In the analysis phase, curriculum analysis and analysis of student needs, interviews with lecturers of algebra and identification of dominant intelligence possessed by students majoring in mathematics education in $2019 / 2020$ were 33 people, from the test obtained five dominant intelligences owned by students namely intelligence verbal/linguistic, logical/mathematical, visual/spatial, interpersonal, and intrapersonal. Furthermore, at the design stage the activities carried out compile student worksheets that are adapted to the dominant intelligence of students and are implemented through learning based on blended learning by utilizing e-learning media google classroom, compiling an assessment instrument for student worksheets. And, at the development stage, content/material and design validation tests were carried out by two experts and practicality tests by five students. From the results of this study were obtained: (1) The results of the validity test conducted by two experts obtained several suggestions for improvement with the conclusion that the student worksheet can be used with revision; (2) Student worksheets based on blended learning that are oriented to multiple intelligences are "feasible" to be used with the percentage of content / material and design feasibility of $80 \%$ and $76.7 \%$, respectively; (3) The quality of student worksheets gets a "good" score from the practicality test with consecutive percentages of $76.4 \%, 74 \%$, and $77.6 \%$ in terms of the presentation of material, appearance, and benefits.
\end{abstract}

Keywords: student worksheets, blended learning, multiple intelligences

\section{INTRODUCTION}

Education plays an important role in preparing quality human resources. Through quality education will produce the next generation that can determine the progress of a nation. However, various problems faced in Indonesia are related to education and have not been resolved to date. One of the ways taken by the government in improving the quality of education is by improving the learning process that starts from the curriculum, methods, strategies and media used in the learning process.

The pattern of education in Indonesia at the elementary, secondary and tertiary levels is still largely based on uniformity and measurement for intelligent students which is limited to IQ. So, in determining the learning design, methods and strategies as well as the media to be used it is still rare to identify the intelligence possessed by students. Where education still emphasizes the ability of mathematical logic and language. This mindset is not appropriate to be applied in the industrial revolution era 4.0.

In the era of the industrial revolution 4.0, various challenges must be faced in the field of science and technology. The development of science and technology needs to be complemented by an increase in human resources (HR). The ability of human resources is not only seen from one's ability to answer IQ tests, but how a person can solve several problems based on his intelligence. According to the intelligence theory that was triggered by Gardner [1] every human being has eight types of intelligence in him with different levels. Gardner[2] human intelligence includes verbal/linguistic, logical/ mathematical, visual/spatial, kinesthetic, musical, interpersonal, intrapersonal, and naturalist intelligence. Intelligence possessed by a person is not only determined by the value achieved, the potential and inherent nature it has but is also determined by one's ability to face and solve problems and make something that can be useful for others[3]. Furthermore, Suparno[4] suggested that multiple intelligences are the skills a person has in solving problems in learning.

Learning is the process of interaction between students and lecturers and learning resources in a learning environment. Where in every learning process students can do activities learning and interaction between students and students, students and lecturers, students and their environment both within the campus and the community. This is in line with the opinion of Natsir, I [5] that learning is a process or activity carried out by someone that is marked 
by changes in experience, attitudes, skills, understanding and other aspects present in a person who is learning as a result of experience and interaction with the environment. The learning process is part of learning where learning is an aid given by educators in this case lecturers so that the transformation of knowledge, attitudes, character and confidence in students can occur.

Based on observations made by the author in the implementation of the lecture process in algebra, several problems were found, namely the still limited learning resources such as reference books, modules, and student worksheets used in lectures, this resulted in inhibition of students' understanding and creativity of the concepts being studied, not yet effective and efficient learning process due to the absence of renewal and use of technology in the learning process, the absence of student worksheets that are adapted to the dominant intelligence possessed by students, the learning process is still centered on lecturers, students tend to be passive so that it impacts on student learning experiences that are not developing, learning outcomes and expected competencies are not achieved well. Furthermore, so far in the lecture process that is an indicator of student success in the learning process is only measured by the level of IQ, according to Goleman [6] IQ only contributes $20 \%$ to someone's success and the remaining $80 \%$ is determined by other factors, which are components of multiple intelligences.

Therefore, it is necessary to develop student worksheets on algebra courses that are tailored to the dominant intelligence possessed by each student so that they can assist lecturers in determining learning designs, methods, strategies and media to be used. Algebra is a basic course and is a prerequisite for studying other interrelated courses. And, in the learning process a lecturer must be able to create a conducive learning atmosphere, and pay attention to matters related to student conditions in learning such as student characteristics which include background, gender, learning style, talent and intelligence. Development of a teaching material in this case student worksheets can support the learning process so that it is easily understood by students[7]

During the lecture process where student worksheets contain sheets of assignments that must be done by students. The use of student worksheets can encourage students to have meaningful knowledge, enjoy the course with learning methods used by lecturers, motivated to learn and solve problems in student worksheets independently and actively during lectures [8]. At present, all learning processes in Indonesia in the western, central and eastern regions are directed to follow digital dynamics marked by massive online open courses (MOOC) such as EdX, Coursera, internet of things, artificial intelligence, biotechnology and other rapid developments.-based learning Online is something that must be applied in the learning process. Where inlearning online students can access material anywhere and anytime. Facing these challenges, the student worksheets that will be developed in the algebra course are adapted to the dominant intelligence of the students and are implemented through based blended learning.

The background to the emergence of blended learning is the existence of new technologies and increasingly dense human mobility. Blended learning is a term of mixing between conventional learning models that are usually done face to face with an internet-based learning model known as e-learning[9]. E-learning is learning by utilizing internet technology to improve learning environments with rich content and broad coverage. The use of e-learnig in learning is a set of solutions that can increase knowledge and skills. Furthermore, e-learning is a process of distance learning by combining principles in the learning process with technology. The learning process of e-learning is very closely related to blended learning where blended learning becomes part of an effort to use technological advances in improving the quality of learning. Furthermore, Finn and Bucceri[10] put forward something similar to the opinion of [9] that blended learning is a combination ofactivities elearning, namelylearning online with traditional activities, namely face to face. Blended learning is an activity that combineslearning online with face to face (face to face) that can be used by anyone (everyone), anywhere (everywhere) and anytime (anytime), where educators or lecturers can design and choosemedia e-learning that will be used such as google classroom, moodle, edmodo, zoom and several otherapplications e-learning. Learning by using blended learning adjusted to the dominant intelligence possessed by students can increase the activeness and motivation of student learning in algebra.

\section{RESEARCH METHODS}

The research method used is research and development (R\&D) with the ADDIE (modelAnalysis-DesignDevelopment-Implementation-Evaluation)developed by Reiser and Mollenda. ADDIE model is one of the research design models with simple and easy to understand design stages. This model uses 5 stages of development[11], but in this study, the authors limit only to the third stage namely: (1) Analysis; (2) Design; and (3) Development. This research was conducted at the Department of Mathematics Education at Musamus Merauke University. In this study, the authors emphasize the preparation of student worksheets based on blended learning oriented to multiple intelligences for use in algebra courses. This research utilizes google classroom asmedia e-learning in blended learning, where the media is used to distribute student worksheets to students and become a means of discussion and evaluation in the lecture process. As for the stages in this study, namely:

\section{A. Analysis}

At the analysis stage a curriculum analysis and needs analysis are carried out that will help in knowing the constraints and needs of students in algebra courses. At this stage, interviews were also conducted with lecturers supporting algebra courses to find out the constraints faced in the learning process. Next, a multiple intelligence test is performed to identify the dominant intelligence possessed by students using the talent test compiled by[12].

\section{B. Design}

At the design stage, the student worksheet is designed and compiled that is adjusted to the dominant intelligence of the students and is implemented through learning based on blended learning by utilizing themedia e-learning of google classroom; arrange assessment instruments for student worksheets 


\section{Development}

At the development stage, a validity test was conducted by two validator in their fields by completing a questionnaire consisting of 22 questions on the content/material and design aspects. Then, continued with the practicality test conducted by five students majoring in mathematics education. For the percentage criteria for content / material and design feasibility as well as practicality test criteria related to student worksheets based on blended learning oriented to multiple intelligences can be seen in the following table.

TABLE I. PERCENTAGE CRITERIA FOR FEASIBILITY OF CONTENT/MATERIAL AND DESIGN

\begin{tabular}{|c|c|}
\hline Percentage (\%) & Criteria \\
\hline $81-100$ & Very Feasible \\
\hline $61-80$ & Feasible \\
\hline $41-60$ & Enough Feasible \\
\hline $21-40$ & Low Feasible \\
\hline $0-20$ & Not Feasible \\
\hline
\end{tabular}

TABLE II. CATEGORIES OF PRACTICALITY TESTS ON WORKSHEETS BASED ON BLENDED LEARNING ORIENTED TO MULTIPLE

\begin{tabular}{|c|c|}
\hline Percentage (\%) & Criteria \\
\hline$>80$ & Very Good \\
\hline $60-80$ & Good \\
\hline $40-60$ & Enough Good \\
\hline $20-40$ & Low Good \\
\hline $0-20$ & Not Good \\
\hline
\end{tabular}

\section{RESUlTS AND DisCUSSIONS}

The results of this study are to produce worksheets based on blended learning that are oriented towards multiple intelligences in algebra. The characteristics of the development of student worksheets are oriented to the five dominant intelligence possessed by students. This student worksheet is used as a medium in the algebra lecture process. Stages of the procedure for developing student worksheets are carried out as follows:

\section{A. Analysis}

At this stage the activities carried out analyze the algebra semester learning plan. The analysis was compiled based on observations of curriculum analysis

through Graduate Learning Achievement, Study Program Achievement and Subject Learning Achievement. Furthermore, a needs analysis is carried out covering facilities, infrastructure and other needs needed by students to facilitate the learning process. Then, conducting interviews with lecturers supporting algebra subjects with the aim of knowing the implementation of learning, the obstacles encountered and the quality of the learning process. And, the next step is to conduct a multiple intelligence test to identify the dominant intelligence possessed by students using a talent test consisting of 80 statements for verbal/linguistic, logical mathematical, visual/spatial, kinesthetic, musical, interpersonal, intrapersonal, and naturalist intelligence.

TABLE III. CATEGORIES OF PRACTICALITY TESTS ON WORKSHEETS BASED ON BLENDED LEARNING ORIENTED TO MULTIPLE

\begin{tabular}{|c|l|c|c|}
\hline No & \multicolumn{1}{|c|}{ Multipel Intelligence } & Score & Percentage (\%) \\
\hline 1 & $\begin{array}{l}\text { Verbal / Linguistic } \\
\text { Intelligence }\end{array}$ & 631 & $63,1 \%$ \\
\hline 2 & $\begin{array}{l}\text { Logical / Mathematical } \\
\text { Intelligence }\end{array}$ & 642 & $64,2 \%$ \\
\hline 3 & Visual / Spatial Intelligence & 610 & $61 \%$ \\
\hline 4 & Kinesthetic Intelligence & 492 & $49,2 \%$ \\
\hline 5 & Musical Intelligence & 566 & $56,6 \%$ \\
\hline 6 & Interpersonal Intelligence & 654 & $65,4 \%$ \\
\hline 7 & Intrapersonal Intelligence & 613 & $61,3 \%$ \\
\hline 8 & Naturalist Intelligence & 440 & $44 \%$ \\
\hline
\end{tabular}

Identification test results based on the table of student intelligence identification test results obtained by five dominant students intelligence namely verbal/linguistic intelligence with a percentage of $63.1 \%$, logical/mathematical intelligence at $64.2 \%$, visual spaced intelligence at $61 \%$, interpersonal intelligence by $65.4 \%$ and intrapersonal intelligence by $61.3 \%$. Although the percentage of other intelligence is not too far, but the chosen one is the intelligence that has a higher percentage value. In this study, the authors chose five dominant intelligences determined from percentage values above $60 \%$.

\section{B. Design}

At this stage the activities carried out are determining the material to be developed and adjusted to the dominant intelligence of students, doing the design related to the design of student worksheets to make it look attractive, easy to understand, and to be carried out blended which is divided into 4 main stages, namely face to face - online learning face to face - online learning. Activities face to face before going online aims to provide an initial understanding related to the learning process undertaken and the media e-learning that will be used. After activities face-to-face students will be faced with learning online, in this activity students are given material as an online discussion material. After activities online students will be confronted again with face to face, activities in this activity students present and make conclusions related to the material discussed in online learning. And the last basic stage is an online discussion after face to face, in this activity students work on the exercises contained in the student worksheet. Next, compile an assessment instrument for student worksheets related to the content/material and design provided to the validator and prepare assessment instruments related to aspects of the presentation of material, appearance and benefits to be given to students.

\section{Development}

At this stage the activities carried out are product validity tests and practicality tests. The product validity test was carried out by two validators and the practicality test was carried out by five students.

Validation test by two validators aims to obtain an assessment so that the validity level of a student worksheet 
can be known, in addition to the validity test can find out the weaknesses of a student worksheet that was developed by asking suggestions for improvements to improve student worksheets. Furthermore, the suggestions from the validator serve as a reference for revising student worksheets to make it better. While the practicality test aims to determine the level of practicality in terms of the presentation of the material, appearance and benefits of the student worksheets developed.

\section{1) Test validity}

Student worksheets were developed, tested to two validators namely mathematics education lecturer IAIN Palopo and mathematics education lecturer UKI Toraja by giving a questionnaire containing 22 questions related to the content/material and design of student worksheets by utilizing google forms. The suggestions for improvement in the validation test of student worksheets are as follows:

TABLE IV. SUGGESTIONS FOR IMPROVEMENT IN THE VALIDITY TEST OF STUDENT WORKSHEETS

\begin{tabular}{|l|l|l|}
\hline \multirow{2}{*}{$\begin{array}{c}\text { Learning } \\
\text { Media }\end{array}$} & \multicolumn{2}{|c|}{ Suggestions for improvement } \\
\cline { 2 - 3 } & \multicolumn{1}{|c|}{ Validator 1 } & \multicolumn{1}{c|}{ Validator 2 } \\
\hline Worksheet & $\begin{array}{l}\text { - Improve writing and } \\
\text { sentences in the problem }\end{array}$ & $\begin{array}{l}\text { - Improve grammar on } \\
\text { student worksheets }\end{array}$ \\
\cline { 2 - 3 } & $\begin{array}{l}\text { - Add material and } \\
\text { questions to the student } \\
\text { worksheet }\end{array}$ & $\begin{array}{l}\text { - The preparation of } \\
\text { questions is adjusted to } \\
\text { the level of difficulty by } \\
\text { referring to the cognitive } \\
\text { level of bloom's } \\
\text { taxonomy, but it is still } \\
\text { adjusted to the dominant } \\
\text { intelligence of students }\end{array}$ \\
\cline { 2 - 3 } & $\begin{array}{l}\text { - Improve the structure and } \\
\text { design of student } \\
\text { worksheets }\end{array}$ & $\begin{array}{l}\text { - Improve designs } \\
\text { related to the } \\
\text { appearance of student } \\
\text { worksheets }\end{array}$ \\
\hline
\end{tabular}

The validation test process for student worksheets that the authors developed was carried out twice until the validator stated that the student worksheets were suitable for use. In the first validation stage, there are several suggestions for improvement by two validators. After the student worksheets were improved, then the student worksheets were given to two validator to be reassessed, the results showed all the experts gave positive responses and the student worksheets had fulfilled all components in accordance with the assessment of the instruments that were made with interpretation can be used with several revisions. Assessments given by two validators on the developed student worksheets can be seen in the following table.
TABLE V. RECAPITULATION OF STUDENT WORKSHEET ANNOUNCEMENTS BASED ON BLENDED LEARNING ORIENTED TO MULTIPLE INTELLIGENCES

\begin{tabular}{|c|c|c|c|c|}
\hline \multirow[t]{2}{*}{ Component } & \multicolumn{2}{|c|}{$\begin{array}{c}\text { Percentage }(\%) \text { of } \\
\text { Feasibility }\end{array}$} & \multirow{2}{*}{$\begin{array}{c}\text { Average } \\
\text { Feasibility } \\
\text { Percentage } \\
(\%)\end{array}$} & \multirow[t]{2}{*}{ Criteria } \\
\hline & Validator 1 & Validator 2 & & \\
\hline $\begin{array}{l}\text { Content/ } \\
\text { Material }\end{array}$ & 79,3 & 78,5 & $80 \%$ & Feasible \\
\hline Design & 77,5 & 77,8 & $76,7 \%$ & Feasible \\
\hline
\end{tabular}

From the data obtained an average percentage of the feasibility of student worksheets for content / material components by $80 \%$ and design components by $76.7 \%$ with the interpretation that student worksheets based on blended learning that are oriented to multiple intelligences developed have reasonable criteria to be used.

\section{2) Test Praticality}

The practicality test of a student worksheet based on blended learning that is oriented to multiple intelligences is carried out by five students. The recapitulation of practicality results can be seen in the following table.

\begin{tabular}{|c|c|c|c|c|c|c|c|}
\hline \multirow{2}{*}{ Aspect } & \multicolumn{5}{|c|}{$\begin{array}{c}\text { Percentage } \\
(\%)\end{array}$} & $\begin{array}{c}\text { Average } \\
\text { Percentage } \\
(\%)\end{array}$ & Criteria \\
\cline { 2 - 6 } & $\mathbf{1}$ & $\mathbf{2}$ & $\mathbf{3}$ & $\mathbf{4}$ & $\mathbf{5}$ & 76,4 & Good \\
\hline $\begin{array}{c}\text { Presentation } \\
\text { of Material }\end{array}$ & 75 & 77 & 78 & 75 & 77 & Good \\
\hline Display & 69 & 75 & 73 & 77 & 76 & 74 & Good \\
\hline Benefits & 78 & 80 & 78 & 77 & 75 & 77,6 & 76 \\
\hline
\end{tabular}

Based on the results of the practicality test conducted by five students related to student worksheets based on blended learning oriented to multiple intelligences, the average practicality test for aspects of material presentation, appearance, and benefits respectively was $76.4 \%, 74 \%$, and $77.6 \%$ with the interpretation that the quality of student worksheets is "good" in terms of material presentation, appearance and benefits.

The results of the validity test conducted by two validators and practicality tests conducted by five students obtained the percentage of eligibility for content / material by $80 \%$ and design by $76.7 \%$, and the percentage of practicality tests for aspects of material presentation by $76.4 \%$, a display of $74 \%$ and a benefit of $77.6 \%$ with the interpretation of student worksheets based on blended learning oriented to multiple intelligences that have decent quality and are practical to use. Student worksheets that are developed are said to be practical for several reasons, including activities and questions provided that can train students' ability to recognize and develop their intelligence. Furthermore, it is practical in terms of the learning process because it can be done outside of face-to-face classroom learning time.

\section{CONCLUSION}

Based on the results and discussion, the conclusion of this research is that a blended learning-based student worksheet which is oriented towards multiple intelligences in algebra courses. Based on the validation assessment of the two developed device validators, the feasibility percentage obtained from the two validators were $80 \%$ and $76.7 \%$, respectively. And the results of practicality tests conducted by five students on student worksheets have good quality 
with the average percentage of practicality tests of the five students in a row namely $76.4 \%, 74 \%$, and $77.6 \%$.

\section{ACKNOWLEDGMENT}

The author wants to thank the Rector of Universitas Musamus and a friend of mathematics education lecturer and the validators who have set aside their time to test the feasibility of the student worksheets developed.

\section{REFERENCES}

[1] T. Armstrong, Multiple Intelligences in The Classroom (2nd Ed) (Terjemahan). Bandung: Kaifa, 2004.

[2] Uno, B Hamza dkk, Mengelola Mengelola Kecerdasan Dalam Pembelajaran. Jakarta: Bumi Aksara, 2009

[3] H. Gardner, Multiple Intellegences:Kecerdasan Majemuk Teori Dalam Praktek. Batam: Interaksara, 2003.

[4] P. Suparno, Teori Inteligensi Ganda dan Aplikasinya di Sekolah. Yogyakarta: Kanisius, 2004.

[5] N. Irmawaty, "The Influence of Classroom Climate and Interpersonal Intelligence toward the Emotional Intelligence and the Correlation to Learning Outcomes in Mathematics of Class VII Students at SMP Negeri in Biringkanaya Subdistrict of Makassar." 2014

[6] M. Intelligences, H. Gardner, M. Cerdas, and M. Cerdas, "The development of 'cerdas' learning model based on multiple intelligences theory in science classroom," vol. 4, no. 2.

[7] D. Nataria and M. S. Rokhman, "Pengembangan Modul Statistika Matematika I Berbasis Universitas Pancasakti Tegal.”

[8] D. Lorida, "Pengembangan Lembar Kerja Mahasiswa Berbasis Masalah Dan Proyek Pada Matakuliah Analisis Data." J.Pendidikan vol. 14, n.2, pp.53-61, 4 Sep. 2013

[9] B. H. Uno, Model Pembelajaran. Jakarta: Bumi Aksara, 2011.

[10] W. Suana, "pengembangan lembar kerja siswa blended learning berorientasi higher order thinking skilss development of blended learning student worksheet oriented with higher order thinking skills," vol. 2, pp. 69-77, 2018.

[11] P. Addie and J. Cikutra, "Pengembangan Aplikasi Multimedia Pengenalan Pemanasan Global Dan Solusinya Menggunakan," pp. 2-4, 2013.

[12] P. Winarto, Maximing Your Talent (Menemukan dan Memaksimalkan Potensi Diri). Libri, PT BPK Gunung Mulia, 2010. 